\title{
PENGARUH PROMOSI PENJUALAN TERHADAP KEPUTUSAN PEMBELIAN BAHAN BANGUNAN PADA UD. SUMATRA BAJA DI BANDAR LAMPUNG
}

\author{
Hazairin Habe ${ }^{(1)}$, Fauziah Wulandari( ${ }^{(2)}$ \\ Fakultas Ekonomi Universitas Sang Bumi Ruwa Jurai \\ hazairin.habe@fe.saburai.ac.id,fauziahwulandari2@gmail.com
}

\begin{abstract}
Abstrak. Perusahaan harus mampu mengenali secara dini apa yang mejadi kebutuhan dan harapan konsumen saat ini maupun masa yang akan datang. Mempelajari dan menganalisa perilaku konsumen dalam keputusan pembelian adalah hal yang penting sebab dengan pengetahuan dasar yang baik mengenai perilaku konsumen akan dapat memberikan masukan yang bearti bagi perencanaan strategi pemasaran.Objek penelitain ini adalah UD. Sumatra Baja di jalan Soekarno Hatta Baypass III no.3 Labuhan Dalam Bandar Lampung. Tujuan dari penelitian ini adalah untuk mengetahui pengaruh promosi penjualan terhadap keputusan pembelian bahan bangunan pada UD. Sumatra Baja Bandar Lampung. Hasil penelitian menunjukan adalah melalui Uji hipotesis parsial melalui uji test diperoleh nilai $t_{\text {hitung }}$ antara promosi penjualan terhadap keputusan pembelian sebesar 11,685 dan $t_{\text {hitung }}=11,685>t_{\text {tabel }} 1,679$. Persamaan regresi antara promosi penjualan dan keputusan pembelian pada UD. Sumatra Baja adalah sebesar $Y=0,819+0,929 \mathrm{X}+\mathrm{e}$, yang menunjukkan setiap kenaikan satu point dari variabel promosi penjualan akan diikuti oleh naiknya variabel keputusan pembelian pada UD. Sumatra Baja sebesar 0,929 point.
\end{abstract}

Kata kunci: Promosi, Perusahaan, Masyarakat.

\section{PENDAHULUAN}

Pembangunanan dunia saat ini berjalan dengan pesat, yang menciptakan suatu persaingan yang semakin ketat. Hal ini yang menuntut produsen untuk lebih peka dan kritis terhadap perubahan yang ada baik politik, budaya, sosial, maupun ekonominya. Syarat yang harus dipenuhi oleh suatu perusahaan agar dapat tercapai sukses dalam persaingan adalah berusaha mencapai tujuan untuk menciptakan dan mempertahankan pelanggan. Agar tujuan tersebut tercapai maka setiap perusahaan harus berupaya menghasilkan barang dan jasa yang diinginkan konsumen dengan harga yang pantas. Dengan demikian, setiap perusahaan harus mampu memahami kelangsungan hidup perusahaan tersebut sebagai organisasi yang berusaha memenuhi kebutuhan dan keinginan para konsumennya.
Perusahaan harus bekerja keras membuat kebijakan-kebujakan strategis baru dalam menjual produk dan jasa mereka dalam kaitannya menghadapi persaingan yang ketat dengan competitor yang dapat memberikan value yang lebih besar kepada costumer. Pada dasarnya dengan semakin banyaknya pesaing maka semakin banyak pula pilihan bagi pelanggan untuk dapat memilih produk yang sesuai dengan apa yang menjadi harapan. Konsekuensinya atas perubahan tersebut adalah pelanggan menjadi lebih cermat dan pintar dalam menghadapi setiap produk yang diluncurkan dipasar. Masyarakat kini mulai berpikir selektif smart dalam memilih suatu produk, sehingga mereka akan mendapatkan produk yang berkualitas. Ketatnya persaingan akan memposisikan pemasok untuk selalu mengembangkan dan merebut market share.

Perusahaan harus mampu mengenali secara dini apa yang menjadi kebutuhan dan 
harapan konsumen saat ini maupun masa yang akan datang. Mempelajari dan menganalisa perilaku konsumen dalam keputusan pembelian adalah hal yang penting sebab dengan pengetahuan dasar yang baik mengenai perilaku konsumen akan dapat memberikan masukan yang bearti bagi perencanaan strategi pemasaran.

Strategi pemasaran terdiri dari unsurunsur pemasaran yang terpadu dalam 4P, yaitu Product, Price, Promotion, place yang selalu berkembang sejalan dengan gerak perusahaan dan perubahan-perubahan lingkungan pemasaran serta perubahan perilaku konsumen. Perilaku konsumen mempunyai implikasi sangat luas terhadap perumusan strategi pemasaran. Hal ini disebabkan karena strategi pemasaran menyangkut dua kegiatan pokok yang diantaranya adalah pemilihan pasar-pasar yang akan dijadikan sasaran pemasaran serta merumuskan dan menyusun suatu kombinasi yang tepat dari marketing mix agar kebutuhan konsumen dapat dipenuhi secara memuaskan. Salah satu keunggulan dalam persaingan ini terutama adalah kualitsas produk yang dapat memenuhi keinginan konsumen. Bila tidak sesuai dengan spesifikasi maka produk akan ditolak.

Pengulangan pesan berpengaruh positif terhadap pembelajaran konsumen.

Konsumen yang membeli atau menggunakan suatu produk setelah melihat iklannya yang berulang-ulang dan ia meyakini produk tersebut, maka konsumen tersebut telah melakukan proses belajar melalui proses penyampaian stimulus yang berulang (Handayani, 2009). Iklan adalah sumber informasi utama dalam pengambilan keputusan. Kegiatan periklanan adalah salah satu alat promosi utama yang sering digunakan untuk mengarahkan komunikasi yang bersifat membujuk kepada yang ditujunya.

Perusahaan yang telah melakukan pengembangan produk salah satunya adalah
UD. Sumatra Baja yang bergerak dibidang penjualan bahan bangunan. Melihat prosepk pasar yang cukup cerah maka perusahaan ini selalu mengikuti perkembangan pasar. Adapun produk yang telah dijual seperti keramik, besi triplek, dan alat bangunan lainnya. Perusahaan ini adalah perusahaan perseorangan yang dibangun pada tanggal 1 Januari 2014. Menurut (Swastha dan Handoko, 2008 : 110) mengemukakan bahwa keputusan pembelian merupakan proses dalam pembelian yang nyata, apakah membeli atau tidak. Dengan permasalahan diatas, penulis ingin mengkaji dengan judul "Pengaruh Promosi Penjualan Terhadap Keputusan Pembelian Bahan Bangunan Pada UD. Sumatra Baja Bandar Lampung."

\section{KAJIAN TEORI}

\section{Pengertian Promosi}

Menurut (Suryana, 2001: 112), promosi adalah cara mengkomunikasikan barang dan jasa yang di tawarkan supaya konsumen mengenal dan membeli.

Menurut (Kusmono, 2001 : 374) definisi promosi adalah usaha yang dilakukan pasar untuk mempengaruhi pihak lain agar berpartisipasi dalam kegiatan pertukaran. Sedang menurut (Madura, 2001: 157), promosi adalah tindakan menginformasikan atau mengingatkan tentang spesifikasi produk atau mereka.

\section{Tujuan Promosi}

Tujuan promosi mengakibatkan keinginan para konsumen untuk membeli produk atau jasa yang dihasilkan. Oleh sebab itu, harus di usahakan bagai mana mempengaruhi berfikir konsumen akhir meyakinkan pembeli. Sedangkan kata promosi harus baik dan menarik, sehingga memberi kesan bahwa pembeli tidak 
menghendaki produk yang lain selain dari barang yang ditawarkan kepadanya.

Menurut (Kismono, 2001: 374), perusahaan perlu menetapkan tujuan promosi yang akan membantu tercapainya tujuan perusahaan secara lebih luas. Program-program promosi dapat didasarkan atas satu atau lebih tujuan berikut ini:

1. Memberikan informasi. Tujuan dasar dari semua kegiatan promosi adalah memberikan informasi kepada konsumen potensial tentang produk yang ditawarkan, dimana konsumen dapat membelinya, dan berapa harga yang ditetapkan. Konsumen memerlukan informasi-informasi tersebut dalam pengambilan keputusan pembeliannya.

2. Meningkatkan penjualan. Kegiatan promosi juga merupakan salah satu cara meningkatkan penjualan. Perusahaan dapat merancang promosi penjualan dengan memberikan kupon belanja, sampel produk dan sebagainya. Untuk membujuk konsumen mencoba produk yang ditawarkan dengan harga yang lebih murah atau dengan tambahan keuntungan yang lain.

3. Menstabilkan penjualan. Pada saat pasar lesu, perusahaan perlu melakukan kegiatan promosi agar tingkat penjualan perusahaan tidak mengalami penurunan yang berarti.

4. Memposisikan produk. Perusahaan perlu memposisikan produknya dengan menekankan keunggulan produknya dibandingkan produk pesaing. Strategi promosi yang tepat, seperti iklan, dapat membantu perusahaan.

5. Membentuk citra produk. Kegiatan promosi yang dilakukan perusahaan dapat membantu image konsumen terhadap produk yang ditawarkan. Perusahaan dapat menggunakan media iklan untuk membangun cirta produknya dimata konsumen.
Menurut Kismono, promosi terdiri dari enam variabel yaitu :

1. Iklan

Iklan merupakan promosi yang sangat dikenal oleh masyarakat konsumen. Hampir setiap saat konsumen mendengar atau membaca berbagai iklan, baik di media cetak maupun di media elektronik. Iklan di definisikan sebagai komunikasi non personal yang dibiayai sponsor (organisasi maupun individu) melalui berbagai media. Media yang dapat digunakan meliputi: surat kabar, televisi, direct mail (katalog, brosur), radio, majalah, outdoor displays (bilboard, poster), dan lain-lain. Iklan dapat dikategorikan menjadi:

a. Retail advertising, yaitu iklan yang digunakan oleh pengecer untuk mempengaruhi konsumen akhir.

b. Trade advertising, yaitu iklan yang dilakukan oleh konsumen untuk mempengaruhi perantara pemasaran ; pedagang besar dan produser.

c. Industrial advertising, yaitu iklan yang dilakukan produsen untuk mempengaruhi produsen-produsen lain yang mungkin menggunakan produknya.

d. Intitusional advertising, yaitu periklanann yang ditujukan bukan untuk menjual produk, namun untuk lebih memperkenalkan intitusi atau organisasi perusahaanya.

\section{Personal selling,}

Personal seling atau penjualan personal adalah komunikasi tatap muka langsung untuk mempromosikan barang atau jasa menemukan prospek penjualan, dan memberikan layanan pasca penjualan. Tiga karakteristik khusus penjualan personal adalah:

a. Melibatkan hubungan yang hidup, cepat, dan interaktif antara duaorang atau lebih.

b. Memungkinkan semua jenis hubungan berkembang menjadi lebih mendalam 
sehingga lebih mendalam sehingga meningkatkan minat pelanggan, dan

c. Membuat pembeli merasa berkewajiban untuk mendengar wiraniaga dan memberikan respon balik.

\section{Promosi dari Mulut ke Mulut}

Promosi dari mulut kemulut terjadi jika konsumen membicarakan, baik secara negatif maupun positifnya. Menurut penelitian-penelitian yang diakukan oleh Departemen Urusan Konsumen White House Office terungkap bahwa konsumen yang tidak puas akan menceritakan pengalaman buruknya kepada sembilan orang temanya. Untuk mengurangi efek negatif dari promosi dari mulut kemulut tersebut, ada beberapa hal yang di lakukan manajemen :

a. Menumbuhkan cerita yang positif dengan membuat hal yang biasa menjadi tidak biasa.

b. Melonggarkan kebijakan pengembalian produk, periksa produk lebih teliti sebelum produk itu meninggalkan pabrik, gudang atau toko.

c. Memberikan pelayanan yang lebih dari apa yang diharapkan konsumen.

d. Mendengarkan keluhan konsumen dan membantu mereka menyelesaikan masalah.

e. Memperhatikan lingkaran pengaruh promosi dari mulut kemulut.

\section{Public Relations}

Public relation atau hubungan masyarakat adalah fungsi manajemen yang mengevaluasi sikap masyarakat, mengambil kebijakan-kebijakan sesuai dengan kepentingan publik, dan mengambil tindakan-tindakan yang diperlakukan agar publik dapat memahami dan menerima produk perusahaan. Saat ini public relations semakin penting dalam perusahaan untuk menjembatani komunikasi antara perusahaan dengan pelanggan, relasi bisnis, pemerintah atau pihak eksternal yang lain.

\section{Publisitas}

Publisitas merupakan segala bentuk informasi segala tentang individu, produk, organisasi yang mengalir kepada masyarakat melalui mass media tanpa membayar dan diluar kontrol sponsor. Publisitas merupakan bagian dari hubungan masyarakat. Publisitas mempunyai beberapa manfaat yaitu untuk menumbuhkan kesadaran konsumen akan produk perusahaan, membentuk citra positif, mendapatkan pengakuan atas karyawan dan prestasi mereka. mendorong orang-orang untuk berpartisipasi dalam proyek-proyek kemasyarakatan, atau pada saat tertentu untuk melawan pemberitaan-pemberitaan yang negatif.

\section{Promosi penjualan}

Promosi penjualan dapat merupakan sarana promosi yang efektif, tergantung pada karakteristik produknya. Demonstrasi memasak atau demonstrasi penggunaan produk seringkali merupakan cara yang diterima konsumen dan biasa dilakukan ketika perusahaan melakukan pameran.

Promosi penjualan:

1. Untuk konsumen: kupon diskon, rabat, sampel gratis, hadiah, kupon untuk ditukar dengan hadiah, kontes undian berhadiah.

2. Untuk perantara pemasaran : gerobak/ outlet untuk berjualan (poin of purchase display), pinjaman, pemeran dagang, kontes, dan premium (konpesasi tambahan)

\section{METODE PENELITIAN}

\section{Objek Penelitian}

Objek penelitain ini adalah UD. Sumatra Baja di jalan Soekarno Hatta 
Baypass III no.3 Labuhan Dalam Bandar Lampung. Penelitian dilaksanakan dari bulan Juni 2017 sampai dengan Agustus 2017.

\section{Metode dan Teknik Pengumpulan Data}

Dalam penelitian ini jenis data yang diperlakukan adalah :

a. Data Primer

Data primer merupakan data dasar yang akan diperoleh langsung tanpa perantara orang atau lembaga lain sebagai pihak ketiga. Data primer ini diperoleh dengan wawancara melalui responden dengan menggunakan daftar pertanyaan.

\section{b. Data Sekunder}

Data skunder merupakan data yang diperoleh melalui orang lain yang berhubungan dengan permasalahan yang dipecahkan. Data sekunder ini diperoleh melalui cara studi dokumenter yaitu mengumpulkan dan mempelajari brosurbrosur serta dokumen organisasi.

\section{Sampel dan Populasi}

Teknik sampel yang digunakan dalam penelitian ini adalah dengan menggunakan teknik Random Sampling, yaitu menentukan jumlah sampel secara acak, dengan jumlah populasi 184 orang. Besarnya jumlah sampel adalah dengan mengikuti pendapat (Zainal Mustafa, 2004 : 6), yaitu semakin besar sampel yang diambil semakin tinggi tingkat representatifnya terhadap populasi.

Menurut pendapat (Suharsimi Arikunto, 2010) bahwa jika anggota populasi lebih besar dari 100 maka dapat dilakukan metode sampling dengan mengambil sampel sebesar $10 \mathrm{sd} 25 \%$ dari anggota populasi, tetapi jika anggota lebih kecil dari 100 sebaiknya menggunakan metode sensus dengan meneliti seluruh anggota. Dengan dasar tersebut, 25\% x 184
$=46$ orang responden sebagai sampel, mewakili seluruh sifat - sifat dari 184 konsumen.

\section{Metode Analisis Data}

Analisis Kualitatif yaitu pemecahan permasalahan yang dilakukan dengan cara membandingkan antara teori dengan praktek yang dilakukan pada objek penelitian.

Analisis kuantitatif yaitu menganalisis dengan menggunakan angka angka yang dihimpun dari data perusahaan yang berkaitan dengan permasalahan yang dihadapi perusahaan. Dalam analisis kuantitatif ini penulis menggunakan perhitungan dengan SPSS for windows version 20.0 dengan pendekatan rumus Regresi linier Sederhana, dimana formulanya sebagai berikut :

$$
Y=a+b X+e t
$$

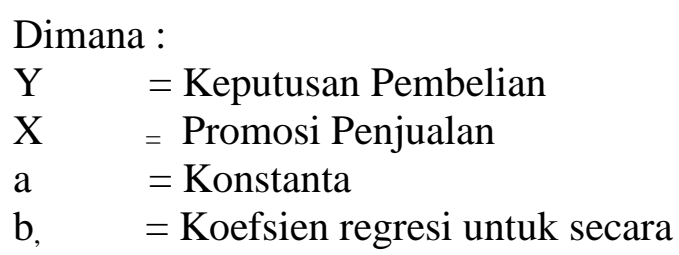

berturut-turut untuk $\mathrm{X}$

et = error term

Untuk pengujian validitas dilakukan dengan menggunakan alat bantu program statistik, dengan kriteria sebagai berikut :

a. Jika $r_{\text {hitung positif dan }} r_{\text {hitung }}>r_{\text {tabel maka }}$ butir pertanyaan tersebut valid.

b. Jika $\mathrm{r}$ hitung negatif atau $\mathrm{r}$ hitung $<\mathrm{r}$ tabel, maka butir pertanyaan tersebut tidak valid.

Untuk mengetahui nilai distribusi nilai $\mathrm{r}_{\text {tabel }}$ nilai Signifikansi $5 \%$ atau 0,05

Uji reliabilitas dilakukan untuk mengetahui seberapa jauh hasil pengukuran tetap konsisten. Untuk melihat reliabilitas masing-masing instrumen yang digunakan, maka peneliti menggunakan koefisien 
cronbach alpha. Suatu instrumen dikatakan reliable jika memiliki nilai cronbach alpha lebih besar dari 0,6 (Ghozali 2009).

Uji statistik t disebut juga sebagai uji signifikasi individual. Uji ini menunjukkan seberapa jauh pengaruh variabel independen secara parsial terhadap variabel dependen.

Kriteria pengambilan keputusan :

1. Dengan melihat nilai signifikan (sig) sebesar 5\%. Bila nilai signifikan (sig) < 0,05 maka Ha diterima dan Ho ditolak yang bermakna model layak digunakan dalam penelitian ini, dan sebaliknya apabila nilai signifikan (sig) $>0,05$ maka Ho diterima dan $\mathrm{Ha}$ ditolak yang bermakna model tidak layak digunakan.

2. Membandingkan nilai $\mathrm{t}$ hasil perhitungan dengan nilai t menurut tabel. Bila t hitung > dari nilai t tabel, maka Ho ditolak dan Ha diterima.

Yang dimaksud dengan Hipotesis nol (Ho) dan Hipotesis alternatif (Ha) adalah:

$\begin{aligned} H o: r=0= & \text { Berarti tidak ada } \\ & \text { pengaruh antara promosi } \\ & \text { penjualan terhadap } \\ & \text { keputusan pembelian } \\ H a: r \neq 0= & \text { Berarti ada pengaruh } \\ & \text { antara promosi penjualan } \\ & \text { terhadap keputusan } \\ & \text { pembelian }\end{aligned}$

\section{HASIL DAN PEMBAHASAN}

Suatu pernyataan dikatakan valid jika pernyataan tersebut mampu mengukur apa yang perlu diukur dan mampu mengungkapkan apa yang ingin diungkap. Pada penelitian ini, uji validitas yang digunakan adalah korelasi product moment. Uji validitas digunakan untuk mengukur pernyataan-pernyataan yang ada dalam kuisioner. Uji validitas dilakukan dengan mengkorelasikan masing-masing pernyataan yang ada dalam kuisioner dengan skor total variabel. Selanjutnya angka korelasi yang dihasilkan akan dibandingkan dengan nilai $r_{\text {tabel }}$ pada $\alpha=0,05$ yaitu sebesar 0,291 dari 46 responden. (Singarimbun, $1995: 139$ )

\section{Analisis kualitatif}

Tabel Distribusi Data Promosi Penjualan (X) secara keseluruhan

\begin{tabular}{|c|c|c|c|c|}
\hline No & Skor & Kategori & Frekuensi & Persentase \\
\hline 1 & $\begin{array}{l}41- \\
50\end{array}$ & $\begin{array}{l}\text { Sangat } \\
\text { Baik }\end{array}$ & 10 & $21,7 \%$ \\
\hline 2 & $\begin{array}{l}31- \\
40\end{array}$ & Baik & 19 & $41,3 \%$ \\
\hline 3 & $\begin{array}{l}21- \\
30\end{array}$ & Sedang & 17 & $37,0 \%$ \\
\hline 4 & $\begin{array}{l}11- \\
20\end{array}$ & Buruk & - & - \\
\hline 5 & $\begin{array}{ll}0 & - \\
10 & \end{array}$ & $\begin{array}{l}\text { Sangat } \\
\text { Buruk }\end{array}$ & - & - \\
\hline \multicolumn{3}{|c|}{$\begin{array}{r}\text { Jumlah } \\
\end{array}$} & 46 & $100 \%$ \\
\hline
\end{tabular}

Sumber : Data Diolah, 2017

Dari 46 orang responde ${ }_{n}$ ruelitian, Promosi Penjualan $(\mathrm{X})$ pada UD. Sumatra Baja dalam kategori "sangat baik" ada 10 orang $(21,7 \%)$, yang menyatakan "baik"ada 19 orang $(41,3 \%)$, dan yang menyatakan "sedang" ada 17 orang (37,0\%). Sedangkan yang menyatakan "buruk" dan "sangat buruk" tidak ada (0\%).

Tabel Distribusi Data Keputusan Pembelian (Y) secara keseluruhan

\begin{tabular}{|c|c|c|c|c|}
\hline $\begin{array}{l}\mathrm{N} \\
\mathrm{O}\end{array}$ & $\begin{array}{l}\text { Sko } \\
\mathrm{r}\end{array}$ & $\begin{array}{l}\text { Kategor } \\
\text { i }\end{array}$ & $\begin{array}{l}\text { Frekuens } \\
\mathrm{i}\end{array}$ & $\begin{array}{l}\text { Persentas } \\
\mathrm{e}\end{array}$ \\
\hline 1 & $\begin{array}{l}41- \\
50\end{array}$ & $\begin{array}{l}\text { Sangat } \\
\text { Baik }\end{array}$ & 8 & $17,4 \%$ \\
\hline 2 & $\begin{array}{l}31- \\
40\end{array}$ & Baik & 20 & $43,5 \%$ \\
\hline 3 & $\begin{array}{l}21- \\
30\end{array}$ & Sedang & 18 & $39,1 \%$ \\
\hline 4 & $\begin{array}{l}11- \\
20\end{array}$ & Buruk & - & - \\
\hline 5 & $\begin{array}{l}0- \\
10\end{array}$ & $\begin{array}{l}\text { Sangat } \\
\text { Buruk }\end{array}$ & - & - \\
\hline \multicolumn{3}{|r|}{ Jumlah } & 46 & $100 \%$ \\
\hline
\end{tabular}

Sumber : Data Diolah, 2017 
Dari 46 orang responden penelitian, Keputusan Pembelian (Y) UD. Sumatra Baja dalam kategori "sangat baik"ada 8 orang $(17,4 \%)$, yang menyatakan "baik"ada 20 orang $(43,5 \%)$, dan yang menyatakan "sedang"ada 18 orang (39,1\%). Sedangkan yang menyatakan "buruk" dan "sangat buruk" tidak ada (0\%).

Berdasarkan hasil jawaban responden diatas dapat dijelaskan bahwa secara umum promosi penjualan dan keputusan pembelian pada UD. Sumatra Baja dalam kondisi baik. Kecenderungan jawaban secara dominan menggambarkan kondisi yang baik ini tentunya bila semakin ditingkatkan akan mendorong peningkatan pembelian pada UD. Sumatra Baja.

\section{Analisis Kuantitatif}

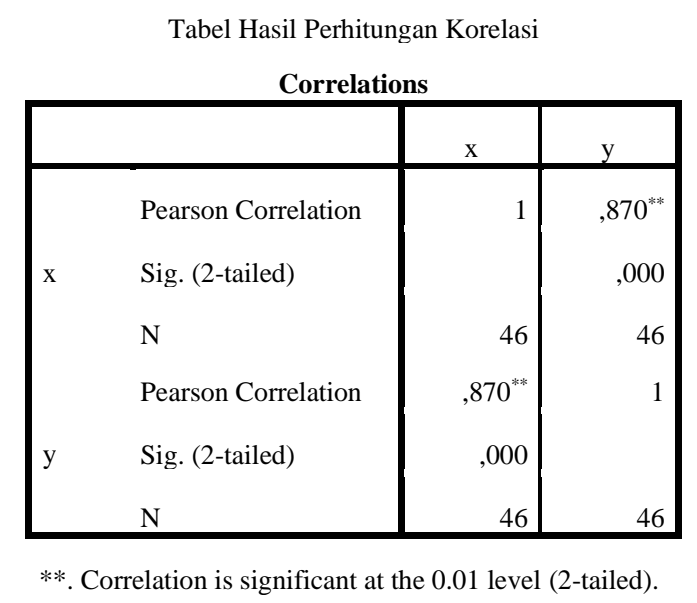

Berdasarkan hasil perhitungan tingkat korelasi antara variabel melalui program SPSS version 20 diperoleh besarnya tingkat korelasi antara variabel Promosi Penjualan (X) dengan variabel Keputusan Pembelian (Y) pada UD. Sumatra Baja adalah sebesar 0,870. Jika dikonsultasikan dengan tabel Kriteria Pengukuran hubungan Koefisien Korelasi (Sudjana 1999) maka tingkat korelasi promosi penjualan (X) dengan variabel keputusan pembelian (Y) pada UD. Sumatra Baja dalam kategori korelasi "tinggi" terletak pada $(0,71-0,90)$.
Tabel Koefisien Determinasi

Model Summary
\begin{tabular}{|l|l|l|l|l|}
\hline Mod & $R$ & $R$ & Adjusted R & Std. Error \\
el & & Square & Square & $\begin{array}{l}\text { of the } \\
\text { Estimate }\end{array}$ \\
\hline 1 &, $870^{\mathrm{a}}$ &, 756 &, 751 & 2,371 \\
\hline
\end{tabular}

a. Predictors: (Constant), $x$

Berdasarkan tabel diatas, diperoleh Koefisien Determinasi (KD) Promosi Penjualan (X) terhadap Keputusan Pembelian (Y) yaitu R2 = 0,756 x 100\% = $75,6 \%$. Hal ini menunjukkan bahwa variabel Promosi Penjualan (X) menjelaskan perubahan terhadap variabel keputusan pembelian (Y) sebesar 75,6\%, sedangkan sisanya dijelaskan oleh faktor lain yang tidak dikaji dalam penelitian ini.

Standard Error of Estimate adalah suatu ukuran banyaknya kesalahan model regresi dalam memprediksikan nilai X. Dari hasil regresi didapat nilai 2,371. Sementara besarnya pengaruh yang diberikan variabel (X) terhadap variabel Y (R Square) adalah sebesar 0,756 atau $75,6 \%$.

\section{Uji Validitas}

Hasil keseluruhan dari pengujian validitas terhadap instrument pernyataan untuk variabel Promosi Penjualan (X) serta Keputusan Pembelian (Y) dapat dilihat pada tabel berikut.

Tabel 1. Uji Validitas Variabel Promosi Penjualan

\begin{tabular}{|c|c|c|c|}
\hline $\begin{array}{c}\text { Item } \\
\text { Pernyataan }\end{array}$ & $\mathbf{r}_{\text {tabel }}$ & $\begin{array}{c}\text { Koefisien } \\
\mathbf{r}_{\text {hitung }}\end{array}$ & Keterangan \\
\hline 1 & 0,291 & 0,528 & Valid \\
\hline 2 & 0,291 & 0,501 & Valid \\
\hline 3 & 0,291 & 0,815 & Valid \\
\hline 4 & 0,291 & 0,725 & Valid \\
\hline 5 & 0,291 & 0,725 & Valid \\
\hline 6 & 0,291 & 0,534 & Valid \\
\hline 7 & 0,291 & 0,305 & Valid \\
\hline 8 & 0,291 & 0,905 & Valid \\
\hline 9 & 0,291 & 0,674 & Valid \\
\hline 10 & 0,291 & 0,602 & Valid \\
\hline Rata - rata & $\mathbf{0 , 2 9 1}$ & $\mathbf{0 , 6 3 1}$ & Valid \\
\hline
\end{tabular}


Sumber : Data diolah, 2017

Berdasarkan tabel dapat dilihat bahwa seluruh item pernyataan tentang Promosi Penjualan memiliki nilai $\mathrm{r}_{\text {hitung }}$ lebih besar dari $r_{\text {tabel }}=0,291$. Dengan nilai rata-rata $\mathrm{r}_{\text {hitung }}=0,631$. Dengan demikian dapat dikatakan bahwa keseluruhan item pernyataan mengenai promosi penjualan tersebut valid dan dapat digunakan sebagai alat ukur penelitian.

Tabel 2. Uji Validitas Variabel Keputusan Pembelian

\begin{tabular}{|c|c|c|c|}
\hline $\begin{array}{c}\text { Item } \\
\text { Pernyataan }\end{array}$ & $\mathbf{r}_{\text {tabel }}$ & $\begin{array}{c}\text { Koefisien } \\
\mathbf{r}_{\text {hitung }}\end{array}$ & Keterangan \\
\hline 1 & 0,291 & 0,428 & valid \\
\hline 2 & 0,291 & 0,378 & valid \\
\hline 3 & 0,291 & 0,743 & valid \\
\hline 4 & 0,291 & 0,496 & valid \\
\hline 5 & 0,291 & 0,632 & valid \\
\hline 6 & 0,291 & 0,452 & valid \\
\hline 7 & 0,291 & 0,379 & valid \\
\hline 8 & 0,291 & 0,813 & valid \\
\hline 9 & 0,291 & 0,592 & valid \\
\hline 10 & 0,291 & 0,491 & valid \\
\hline Rata - rata & $\mathbf{0 , 2 9 1}$ & $\mathbf{0 , 5 4 0}$ & valid \\
\hline
\end{tabular}

Sumber : Data diolah, 2017

Berdasarkan tabel dapat diketahui bahwa seluruh item skor pernyataan tentang keputusan pembelian memiliki nilai $\mathrm{r}_{\text {hitung }}$ dengan nilai rata-rata $r_{\text {hitung }}=0,540$ lebih besar dari $r_{\text {tabel }}=0,291$. Dengan demikian dapat dikatakan bahwa keseluruhan item pernyataan mengenai keputusan pembelian tersebut valid dan dapat digunakan sebagai alat ukur penelitian.

\section{Uji Reliabilitas Data}

Uji reliabilitas digunakan untuk mengetahui layak tidaknya data responden yang digunakan dalam penelitian ini. Instrumen dapat dikatakan reliabel bila memiliki koefisien kehandalan reliabilitas sebesar 0,6 atau lebih. (Uyanto, 2006 : 50). Untuk mengetahui reliabilitas atau tidaknya data variabel penelitian ini dapat diketahui dengan menggunakan alat bantu program statistika SPSS for windows version 20 sehingga diperoleh hasil sebagai berikut:
Hasil dari uji reliabilitas variabel Promosi Penjualan (X) berdasarkan data jawaban responden terhadap 10 pernyataan sebagai berikut:

Uji reliabilitas Promosi Penjualan (X)

\section{Reliability Statistics}

\begin{tabular}{|r|r|}
\hline $\begin{array}{c}\text { Cronbach's } \\
\text { Alpha }\end{array}$ & N of Items \\
\hline, 833 & 10 \\
\hline
\end{tabular}

Berdasarkan hasil uji realibilitas diatas didapat nilai Alpha Promosi Penjualan sebesar 0,833 dan dapat disimpulkan bahwa kuesioner yang digunakan dalam penelitian ini dinyatakan reliabel karena alpha-nya sebesar 0,833 > 0,60. Ini berarti bahwa alat ukur yang digunakan dalam penelitian ini sudah memiliki kemampuan untuk memberikan hasil pengukuran yang konsisten dalam mengukur gejala yang sama.

\section{Tabel Uji Reliabilitas Variabel Keputusan Pembeliaan (Y) Reliability Statistics

\begin{tabular}{|r|r|}
\hline $\begin{array}{c}\text { Cronbach's } \\
\text { Alpha }\end{array}$ & N of Items \\
\hline, 829 & 10 \\
\hline
\end{tabular}

Dari hasil Reliabilitas di atas dapat dilihat nilai Alpha Keputusan Pembelian (Y) sebesar 0,829, dan atas hasil ini dapat disimpulkan bahwa kuesioner yang digunakan dalam penelitian ini dinyatakan reliabel karena nilai alpha-nya sebesar 0,829 $>0,60$.

\section{Uji Hipotesis}

Tabel Uji t 


\section{Coefficients $^{\mathrm{a}}$}

\begin{tabular}{|l|r|r|r|r|r|}
\hline Model & \multicolumn{2}{|c|}{$\begin{array}{c}\text { Unstandardi } \\
\text { zed } \\
\text { Coefficients }\end{array}$} & $\begin{array}{r}\text { Stand } \\
\text { ardize } \\
\mathrm{d} \\
\text { Coeff } \\
\text { icient } \\
\mathrm{s}\end{array}$ & $\mathrm{T}$ & Sig. \\
\cline { 2 - 4 } & $\mathrm{B}$ & $\begin{array}{c}\text { Std. } \\
\text { Error }\end{array}$ & Beta & & \\
\hline $\begin{array}{l}\text { (Cons } \\
\text { tant) } \\
\mathrm{X}\end{array}$ &, 819 & 3,127 & &, 262 &, 795 \\
\hline
\end{tabular}

a. Dependent Variable: $y$

Berdasarkan hasil uji t didapat nilai $t_{\text {hitung }}=11,685$. Apabila dibandingkan dengan $t_{\text {tabel }}$ pada taraf signifikan yaitu 1,679 , maka $t_{\text {hitung }}=11,685>t_{\text {tabel }}=1,679$ sehingga dapat disimpulkan bahwa variabel Promosi Penjualan (X) berpengaruh terhadap keputusan pembelian (Y). Berdasarkan kondisi tersebut, bentuk persamaan regresinya sebagai berikut:

$$
\begin{gathered}
Y=a+b X+e \\
Y=0,819+0,929 X+e
\end{gathered}
$$

Dimana :

$$
\begin{array}{ll}
\mathrm{Y} & =\text { Keputusan Pembelian } \\
\mathrm{a} & =\text { konstanta } \\
\mathrm{b} & =\text { Koefisien Regresi X } \\
\mathrm{X} & =\text { Promosi Penjualan } \\
\mathrm{e} & =\text { error term (tingkat kesalahan) }
\end{array}
$$

Dari persamaan regresi diatas dapat dijelaskan bahwa dengan nilai koefisien promosi penjualan yang positif menunjukkan apabila promosi penjualan meningkat baik maka keputusan pembelian akan meningkat. Nilai koefisien promosi penjualan sebesar 0,929 menunjukkan apabila promosi penjualan meningkat sebesar 1 satuan maka keputusan pembelian juga akan meningkat sebesar 0,929 satuan.

\section{KESIMPULAN DAN SARAN}

\section{Kesimpulan}

Dari hasil penelitian dan pembahasan, maka penulis menyimpulkan sebagai berikut :

Hasil penelitian menunjukkan bahwa promosi penjualan (X) pada UD. Sumatra Baja dalam kategori baik. Untuk perhitungan pengaruh variabel promosi penjualan pada tabel diatas diperoleh angka $\mathrm{R}^{2}$ (R Square) sebesar 0,756 atau 75,6\%. Hal ini menunjukkan bahwa persentase sumbangan pengaruh variabel independen promosi penjualan $(\mathrm{X})$ terhadap variabel dependen keputusan pembelian (Y) sebesar 75,6 dan sisanya dipengaruhi faktor lain. Uji hipotesis parsial melalui uji $\mathrm{t}$ test diperoleh nilai $t$ hitung antara promosi penjualan terhadap keputusan pembelian sebesar 11,685 dan $t_{\text {hitung }}=11,685>t_{\text {tabel }} 1,679$. Persamaan regresi antara promosi penjualan dan keputusan pembelian pada UD. Sumatra Baja adalah sebesar $\mathrm{Y}=0,819+0,929 \mathrm{X}+$ e, yang menunjukkan setiap kenaikan satu point dari variabel promosi penjualan akan diikuti oleh naiknya variabel keputusan pembelian pada UD. Sumatra Baja sebesar 0,929 point. Dapat dilihat bahwa promosi penjualan merupakan bagian penting dalam membuat konsumen untuk memutuskan membeli barang tersebut, maka dengan penelitain ini menunjukkan pengaruh yang signifikan promosi penjualan terhadap keputusan pembelian pada UD Sumatra Baja.

\section{Saran}

Adapun saran-saran yang dapat penulis sampaikan adalah sebagai berikut :

a. Hendaknya perusahaan membuat pengiklanan yang menarik perhatian pembeli, seperti memasang spanduk di tempat strategis, atau memasang iklan di koran.

b. Hendaknya perusahaan memberikan jaminan produknya kepada pembeli, 
sehingga pembeli lebih percaya lagi terhadap produk yang dijual.

\section{DAFTAR PUSTAKA}

Amirullah. 2002. Perilaku Konsumen, Cetakan Pertama. Jakarta: Graha Ilmu.

Arikunto, Suharsimi. 2002. Prosedur Penelitian, Ed Revisi V.Jakarta: Penerbit Rineka Cipta.

Assauri, Soyjan. 2008. Manajemen Produksi dan Operasi. Jakarta: LPFEUI.

Swastha, Basu. Handoko, T. Hani. 2008. Manajemen Pemasaran (Analisa Perilaku Konsumen). Yogyakarta: BPFE UGM.

Ghozali, Imam. 2009. Aplikasi Analisis Multivariate dengan Program SPSS, Ed Keempat. Semarang: UNDIP.

Indriyo, Gitosudarmo. 2008. Manajemen Pemasaran, Edisi Kedua. Yogyakarta: BPFE.

Kismono, Gugup. 2001. Pengantar Bisnis, Edisi Pertama. Yogyakarta: BPFE.

Madura, Jeff. 2001. Pengantar Bisnis, Edisi Pertama. Jakarta: Salemba Empat.

Team. 2017. Pedoman Menulis Skripsi. Bandar Lampung: Fakultas Ekonomi Universitas Saburai.

Saladin, Djaslim. 2006. Manajemen Pemasaran,Edisi Keempat. Yogyakarta: Linda Karya.

Singarimbun, Masri. 1995. Metode Penelitian Survei. Jakarta: LP3S.

Sugiyono. 2004. Metode Penelitian Bisnis. Bandung: Alfabeta.

Sugiyono. 2007. Statistika untuk Penelitian, Cetakan keenam. Bandung: Penerbit Alfabeta.

Sugiyono. 2009. Metode Penelitian Kuantitatif, Kualitatif, dan $R \& D$. Bandung: Penerbit Alfabeta.

Suryana. 2001. Kewirausahaan. Jakarta: Salemba Empat. 